\author{
Research article
}

\title{
Two new species of Kaempferia L. (Zingiberaceae) from Cambodia and Lao PDR
}

\author{
Oudomphone INSISIENGMAY ${ }^{1, *}$, Mark Fleming NEWMAN ${ }^{2} \&$ \\ Thomas HAEVERMANS ${ }^{3}$ \\ 1,3 Institut de Systématique Évolution Biodiversité (ISYEB), Muséum national d'histoire naturelle, \\ Centre national de la recherche scientifique, École Pratique des Hautes Études, \\ Université des Antilles, Sorbonne Université, 57 rue Cuvier, CP 39, 75005 Paris, France. \\ ${ }^{1}$ Cabinet of the Lao Academy of Science and Technology, Ministry of Science and Technology, \\ 100 Building, Na Haidiew Village, Chanthabouly District, Vientiane Capital, Lao PDR. \\ ${ }^{2}$ Royal Botanic Garden Edinburgh, 20A Inverleith Row, Edinburgh EH3 5LR, Scotland, UK. \\ *Corresponding author: Oudomphone_ins@most.gov.la or oudomphone.insisiengmay@mnhn.fr \\ ${ }^{2}$ Email: mnewman@rbge.org.uk \\ ${ }^{3}$ Email: thomas.haevermans@mnhn.fr
}

\begin{abstract}
Two new species of Kaempferia L. (Zingiberaceae), Kaempferia nemoralis Insis. sp. nov. and Kaempferia pascuorum Insis. sp. nov., from Cambodia and Lao PDR are described and illustrated. Morphological similarities to their closely related taxa are discussed. Kaempferia nemoralis Insis. sp. nov. is compared with Kaempferia larsenii Sirirugsa in its vegetative parts, but distinguished by the following characters: whole plant taller, leaf sheath and young shoot apex green, petiole absent. It differs from Kaempferia rotunda L. in its floral parts by the following characters: presence of peduncle, floral tube longer, labellum purple with white line at centre, anther crest obovate, bifid, apex irregularly rounded and ovary glabrous. Kaempferia pascuorum Insis. sp. nov. is compared with Kaempferia larsenii Sirirugsa. Proposed IUCN conservation assessments are also given: Kaempferia nemoralis Insis. sp. nov. occurs in disturbed, open forest and is assessed as CR, whereas Kaempferia pascuorum Insis. sp. nov. occurs in short grassland and is assessed as EN.
\end{abstract}

Keywords. Kaempferia nemoralis Insis. sp. nov., Kaempferia pascuorum Insis. sp. nov., Cambodia, Lao PDR.

Insisiengmay O., Newman M.F. \& Haevermans T. 2020. Two new species of Kaempferia L. (Zingiberaceae) from Cambodia and Lao PDR. European Journal of Taxonomy 712: 1-15. https://doi.org/10.5852/ejt.2020.712

\section{Introduction}

Kaempferia L. (Zingiberaceae, ginger family) is a genus of perennial herbs. Around 40 species are currently accepted (Mabberley 2017), although nearly 140 names are listed in the International Plant Names Index (IPNI 2020). The genus is distributed from India to southern China and Peninsular Malaysia. Several species have medicinal properties, are used in spiritual rituals, or have culinary uses (e.g., Kaempferia galanga L., known as kencur) and are widely cultivated, making it difficult to 
know their natural ranges. The centre of diversity is undoubtedly in the monsoonal parts of SE Asia, particularly Thailand and its immediate neighbours. South of Thailand, the diversity drops sharply with four species reported from Peninsular Malaysia, only one or two of them native (Holttum 1950). To the north, only five species of Kaempferia extend to the tropical provinces of China, and are probably more often cultivated or naturalised than native ones (Wu \& Larsen 2000).

It has been more than a century since the publication of the most recent monograph of all species of Kaempferia (Schumann 1904), and the most recent revision of the genus in Cambodia, Laos and Vietnam (Gagnepain 1908). Revisions of Kaempferia for the Flora of Thailand (T. Jenjittikul et al., in prep.) and in Cambodia, Laos and Vietnam (O. Insisiengmay et al., in prep.) are under way, and have already revealed considerably more species than were known to Gagnepain (1908) who recognised 13 species in Cambodia, Laos and Vietnam. In more recent accounts, nine species were recorded in Lao PDR (Newman et al. 2007), but an additional six have been described in that country in the last 12 years (Koonterm 2008; Picheansoonthon \& Koonterm 2008, 2009b; Picheansoonthon 2009; Phokham et al. 2013), and more are expected from Cambodia and Vietnam. Twenty-seven species are recognised in the current draft of the Flora of Thailand revision (Ruchisansakul, pers. comm.), including 11 described in the last 9 years (Nopporncharoenkul \& Jenjittikul 2017, 2018; Nopporncharoenkul et al. 2020; Phokham et al. 2013; Picheansoonthon \& Koonterm 2009a; Picheansoonthon 2010, 2011; Wongsuwan et al. 2015) and at least three more are to be described.

Many species in the genus are very poorly known taxonomically, mainly because it is so difficult to make informative specimens from these plants, which usually bear only one, extremely delicate and short-lived flower per plant each day of the flowering period. Furthermore, the inflorescence is often held between the leaves and is a complex structure of bracts, bracteoles and a number of flowers at different stages. Several species bloom at night and must be collected in darkness. Others bloom early in the rainy season, before the leaves appear, so to obtain all parts of the plant, two collections must be made a few weeks apart. Therefore, herbarium collections are often of relatively little use to the taxonomist and must be supplemented by living material.

Morphologically, Kaempferia is distinct from other genera of Zingiberaceae. It is classified in the subfamily Zingiberoideae tribe Zingibereae which comprises genera with large, petaloid lateral staminodes, about the same size as the lip. The species of Kaempferia are small herbaceous perennial plants, some with two leaves appressed to the ground, others with erect leaves to about $70 \mathrm{~cm}$ tall. The strongly zygomorphic flowers consist of the usual parts found in Zingiberaceae, an inferior ovary, tubular calyx with three lobes, floral tube with three corolla lobes, a labellum, two lateral staminodes and a single fertile anther with two thecae which hold the style so that the stigma is presented just above the anther. The diagnostic character of the flowers of Kaempferia is the deeply bilobed labellum and large lateral staminodes which are often held in a single plane so that the open flower resembles, at first glance, a tetramerous, salverform flower.

A thorough account of the history of infrageneric classification of Kaempferia is given by Kam (1980), and the correct generic name for the African species by Burtt (1982). The first classification of the species of Kaempferia into infrageneric taxa was made by Horaninow (1862) who described two taxa, Kaempferia [unranked] Soncorus and Kaempferia [unranked] Protanthium. The first of these was described as 'flores centrales' and the second as 'flores praecoces, ante folia e caudice projecti' which is to say that species in the Soncorus group produce their inflorescences terminally on the leafy shoots while those in the Protanthium group produce them early in the growing season, before the leaves, arising from the rhizome. Horaninow placed Kaempferia galanga L. with seven other species in his Soncorus group and $K$. rotunda L. with two other species in his Protanthium group. 
Bentham \& Hooker (1883) gave Horaninow's unranked infrageneric taxa the rank of section and added a third, Kaempferia section Stachyanthesis Benth. \& Hook.f., in which they placed Kaempferia scaposa (Nimmo) Benth. (= Curcuma scaposa (Nimmo) Škorničk. \& M.Sabu) and Kaempferia rosea Schweinf. ex Baker (= Siphonochilus kirkii (Hook.f.) B.L.Burtt). Baker (1890) raised these sections to subgenera and added a fourth, Kaempferia subgenus Monolophus (Wall.) Baker which is now treated as the genus Monolophus Delafosse, Guill. \& Je.Kuhn. Finally, Schumann (1904) recognised 5 subgenera, adding subgenus Cienkowskia K.Schum. to contain the African species now placed in Siphonochilus.

Since K. galanga is the type species of the genus, Kaempferia [unranked] Soncorus is illegitimate; it must be called Kaempferia [unranked] Kaempferia (Turland et al. 2018, Art. 22.2). Insisiengmay et al. (2018) were only able to locate a single element of original material of $K$. rotunda, and it did not match the written description in the protologue, so a proposal to conserve the name with a conserved type was made. This proposal, number 2581, has been recommended by the Nomenclature Committee for Vascular Plants (Applequist 2020).

During fieldwork in Cambodia, Laos and Vietnam in 2016 and 2017, directed towards a revision of Kaempferia in these three countries, we found additional undescribed taxa. Here, we describe two new species, Kaempferia nemoralis Insis. sp. nov. and Kaempferia pascuorum Insis. sp. nov., the first known only in Cambodia, the second distributed in southern Lao PDR and Cambodia. We compare the morphology of these new species to closely related taxa and we also propose a conservation status of each one using IUCN criteria.

\section{Material and methods}

A revision of Kaempferia in Cambodia, Laos and Vietnam formed part of the $\mathrm{PhD}$ thesis of the first author (Insisiengmay 2019). All names applied to species of Kaempferia in these and surrounding countries were examined. Protologues were gathered and specimens, including types at BK, BKF, BM, E, HNL, K, P, QBG, SING and VNM were studied. Herbarium codes follow Index Herbariorum (Thiers, continuously updated). Specimens were collected during field expeditions in Cambodia, Laos and Vietnam from April to August 2016 and May to September 2017. While most collections could be determined to an existing taxon, a small number of collections did not match any herbarium material examined. Among these collections, were the specimens described as two new species below.

Each collection included: flowers and inflorescences in ca 70\% alcohol, dried herbarium specimens, rhizomes for cultivation and leaf material in silica gel for molecular systematic study. A complete set of herbarium vouchers and the living collections were deposited at the National Herbarium, Muséum national d'histoire naturelle $(\mathrm{P})$. The species descriptions are based on the spirit material because dried herbarium specimens lack three-dimensional structures and undergo changes in dimensions of parts of the plants which are very important for species description. The botanical terminology follows the Kew Plant Glossary (Beentje 2016).

IUCN conservation assessments of both species have been made using the Guidelines for Using the IUCN Red list categories and Criteria ver. 3.1 (2012) and ver. 13 (2017). 


\title{
Results
}

\section{Description of new species}

\author{
Order Zingiberales Griseb. \\ Family Zingiberaceae Martinov \\ Subfamily Zingiberoideae \\ Tribe Zingibereae Meisn. \\ Genus Kaempferia L. \\ Subgenus Kaempferia L. (= Soncorus Horan.)
}

Kaempferia nemoralis Insis. sp. nov.

urn:lsid:ipni.org:names:77211164-1

Figs 1-3, Tables 1-2

\section{Diagnosis}

A species of Kaempferia subg. Kaempferia. Vegetative parts similar to K. larsenii by the shape of the leaf blade which is glabrous, parallel-veined and erect but may be distinguished by the following characters: whole plant taller, leaf sheath and young shoot apex green, petiole absent, the flower of Kaempferia nemoralis sp. nov. is completely different from that of $K$. larsenii in orientation, colour and size.

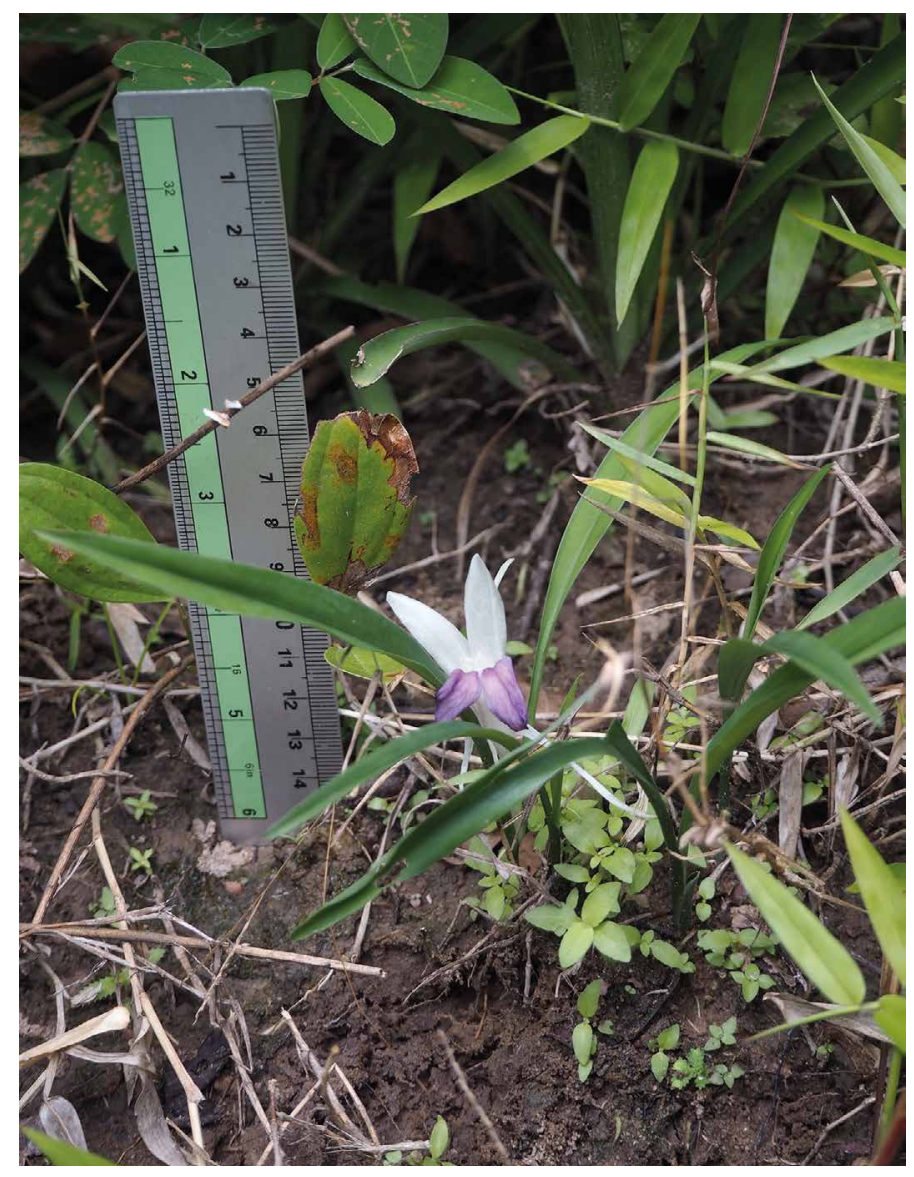

Fig. 1. Kaempferia nemoralis Insis. sp. nov. in natural habitat. Photograph: Oudomphone Insisiengmay. 
Table 1. Comparison of the vegetative parts of Kaempferia larsenii Sirirugsa and Kaempferia nemoralis Insis. sp. nov.

\begin{tabular}{lll}
\hline Characters & Kaempferia larsenii & Kaempferia nemoralis sp. nov. \\
\hline Leaves & & \\
Whole plant height & $8-10 \mathrm{~cm}$ tall & $8-20 \mathrm{~cm}$ tall \\
Leafless sheath colour & Red & Green \\
Young shoot colour & Red & Green \\
Longest leaf blade & $90 \times 10 \mathrm{~mm}$ & $200 \times 20 \mathrm{~mm}$ \\
Petiole & Present & Absent \\
\hline
\end{tabular}

Table 2. Comparison of the floral parts of Kaempferia rotunda L. and Kaempferia nemoralis Insis. sp. nov.

\begin{tabular}{lll}
\hline Characters & Kaempferia rotunda & Kaempferia nemoralis sp. nov. \\
\hline Inflorescence & & \\
Peduncle & Shortly pedunculate & $5 \mathrm{~mm}$ long \\
Floral tube & $50-55 \mathrm{~mm}$ long & $95 \mathrm{~mm}$ long \\
Staminodes & White, purple-tinted, apex acute, & Pure white, apex rounded, \\
& $20 \times 16 \mathrm{~mm}$ & $40 \times 12 \mathrm{~mm}$ \\
Labellum (whole) & Light purple, $40 \times 20-25 \mathrm{~mm}$ & Purple, $47 \times 22 \mathrm{~mm}$ \\
Crest & Oblong, 3-lobed, apex acute, & Obovate, bifid, apex irregularly \\
& $9-12 \times 3-4 \mathrm{~mm}$ & rounded, $10 \times 6 \mathrm{~mm}$ \\
Stamen & $3 \mathrm{~mm}$ long & $10 \mathrm{~mm}$ long \\
Ovary & Villose & Glabrous \\
\hline
\end{tabular}

Inflorescences and flowers similar to those of K. rotunda (Kaempferia subg. Protanthium) by the presence of white staminodes and size of labellum but distinguished by the following characters: presence of peduncle, floral tube longer, $95 \mathrm{~mm}$ long (vs 50-55 mm long in $K$. rotunda), labellum purple with white line at centre, anther crest obovate, bifid, apex irregularly rounded and ovary glabrous, the vegetative parts differ by the shape and indumentum of the leaf blade, and absence of a petiole.

\section{Etymology}

The specific epithet is from the Latin 'nemoralis', meaning 'of woods'. The only known locality is in open forest near a small stream.

\section{Material examined}

\section{Type}

CAMBODIA • Prov. Kratié, Dist. Snuol, Sre Roneam Village, Khseum commune; $12^{\circ} 17^{\prime} \mathrm{N}, 106^{\circ} 25^{\prime}$ E; alt. $74 \mathrm{~m}$; O. Insisiengmay et al. OI 234; 9 Jul. 2017; holotype: $\mathrm{P}$ (dried and spirit coll.); isotype: E (spirit coll. only). 


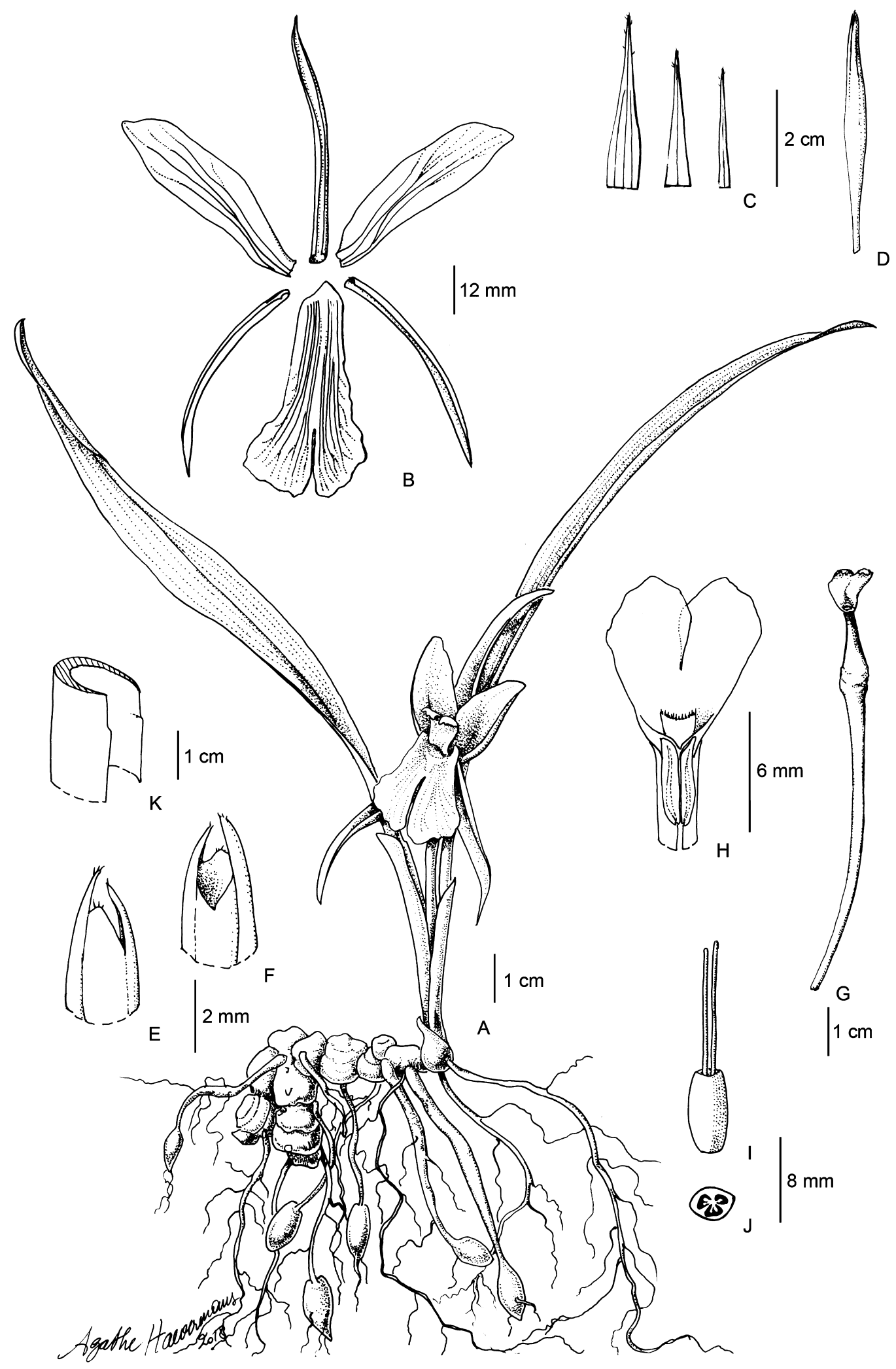

Fig. 2. Kaempferia nemoralis Insis. sp. nov. A. Whole plant. B. Flower dissected. C. Bract and bracteoles. D. Calyx. E. Calyx apex (back view). F. Calyx apex (front view) (dorsal corolla lobe side). G. Floral tube with stamen attached. H. Anther. I. Ovary and epigynous glands. J. Ovary cross section. K. Ligule. Drawing from the type material by Agathe Haevermans (O. Insisiengmay et al. OI 234). 


\section{Description}

Perennial herb, $8-20 \mathrm{~cm}$ tall. Rhizome short, horizontal; roots of two kinds; tuberous, $10-15 \times 3-5 \mathrm{~mm}$, and filamentous. Most individuals with one or two flowering shoots. Leaves 2 with 2 leafless sheaths, green; ligule a very small rim at junction of sheaths and blade, $<1 \mathrm{~mm}$ long, glabrous. Longest leaf blade $200 \times 20 \mathrm{~mm}$, oblong, erect, base attenuate, apex attenuate, glabrous, petiole absent. Inflorescence terminal, peduncle $5 \mathrm{~mm}$ long, flowers $1-3$. Bracts narrowly elliptic to ensiform, villose, $35 \times 7 \mathrm{~mm}$, hyaline, subtending one flower; bracteoles 2 per flower, opposite, narrowly elliptic to ensiform, largest one $27 \times 5 \mathrm{~mm}$, diminishing to $25 \times 2.2 \mathrm{~mm}$, hyaline, villose. Calyx tubular, $50 \times 3 \mathrm{~mm}$ (not flattened), apex with two longer teeth dorsally, greenish and translucent, glabrous and ciliate at apex; floral tube $95 \times 3 \mathrm{~mm}$ (not flattened), glabrous, white; dorsal corolla lobe linear-acuminate, $45 \times 5 \mathrm{~mm}$, white, glabrous, apex with $5 \mathrm{~mm}$ long mucro; lateral corolla lobes linear-acuminate, $40 \times 4 \mathrm{~mm}$, white, glabrous, apex acute; lateral staminodes oblong, $40 \times 12 \mathrm{~mm}$, white, glabrous; labellum obcordate, $47 \times 22 \mathrm{~mm}$, purple with white line at the centre, apex bifid, incision $15 \mathrm{~mm}$, lobes narrowly oblong, emarginate; stamen: filament $10 \mathrm{~mm}$ long, thecae $5 \mathrm{~mm}$ long, dehiscing by longitudinal slits throughout their length, crest obovate, $10 \times 6 \mathrm{~mm}$, bifid, incision $6 \mathrm{~mm}$ deep, apex of sublobes irregularly rounded, white, glabrous; epigynous glands 2, colourless, subulate, $12-13 \mathrm{~mm}$ long; ovary ovoid, $8 \times 3.5 \mathrm{~mm}$, glabrous, trilocular with axile placentation, ovules $3-10$ per locule, $1 \times 0.5 \mathrm{~mm}$; stigma $1.5 \mathrm{~mm}$ long, obcuneiform, curved longitudinally, ostiole ciliate. Fruit unknown.

\section{Distribution and habitat}

Only known from the type locality where the plants were found growing in dry dipterocarp forest, near a stream, in moist, sandy soil at low altitude, $74 \mathrm{~m}$.

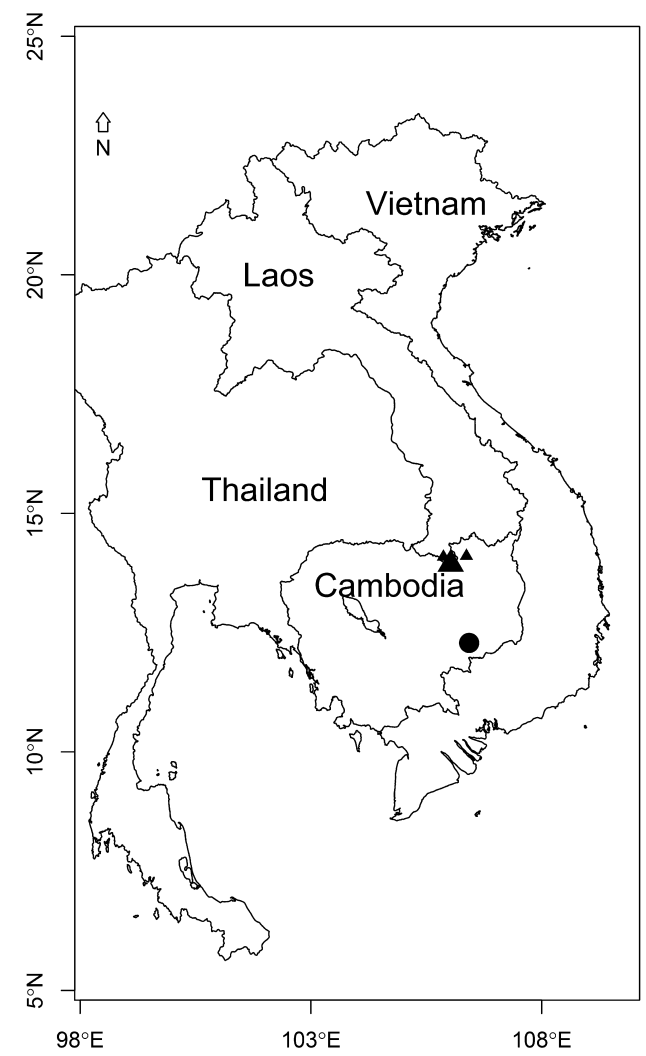

Fig. 3. Distribution of Kaempferia nemoralis Insis. sp. nov. () and Kaempferia pascuorum Insis.

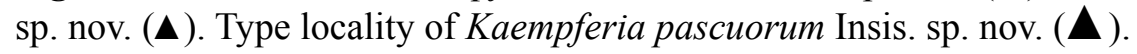




\section{Conservation status}

Proposed IUCN conservation status: $\mathrm{CR}$. AOO $=4 \mathrm{~km}^{2}$, this species is known only from the type locality which is near a path at the edge of a village where tractors and herds of cattle pass frequently. The area is not protected by law. The number of mature individuals is less than 20 .

\section{Notes}

Other species of Kaempferia, not yet determined, were also collected at the type locality of Kaempferia nemoralis sp. nov. These species clearly differ from Kaempferia nemoralis sp. nov. by having their leaves flat on the ground and by a number of characters of the floral parts.

A high-resolution image of the type specimen will be deposited at RUPP, the National Herbarium of Cambodia. Normally, a type specimen would be deposited in the country of origin, but there is very little type material of Kaempferia nemoralis sp. nov. and no paratypes, so it has been agreed with the curator of RUPP that it is better to keep the types at $\mathrm{E}$ and $\mathrm{P}$ where the conditions for long-term conservation, especially of spirit material, are much better.

The collections at the herbaria listed in Material and methods were searched thoroughly, but no material of Kaempferia nemoralis sp. nov. was discovered.

Kaempferia pascuorum Insis. sp. nov. urn:lsid:ipni.org:names:77211165-1

Figs 4-5, Table 3

\section{Diagnosis}

Belonging to Kaempferia subg. Kaempferia and most similar to K. larsenii by its habit, size around 6-10 cm tall, leaf blade erect, similar in shape, parallel-veined and glabrous but distinguished by the following characters: leaf sheath and young shoot apex green, staminodes white, labellum white with purple patch, crest flabellate, apex bifid, irregularly rounded, white.

\section{Etymology}

This species epithet is derived from the Latin 'pascuorum' (of pastures), referring to their habitat.

\section{Material examined}

Type

LAO PDR • Prov. Champassak, Dist. Khong, Cambodian-Laotian border; $13^{\circ} 56^{\prime} \mathrm{N}, 106^{\circ} 1^{\prime} \mathrm{E}$; alt. $84 \mathrm{~m}$; O. Insisiengmay et al. OI. 116; 16 Jun. 2016; holotype: HNL (dried coll. only); isotypes: E (dried coll. only), P (dried and spirit coll.), RUPP (dried coll. only).

\section{Additional material}

CAMBODIA - Prov. Stung Treng, Dist. Siem Pang, Siem Pang Village, Sekong Commune; $14^{\circ} 6^{\prime} \mathrm{N}$, $106^{\circ} 22^{\prime} \mathrm{E}$; alt. $71 \mathrm{~m}$; O. Insisiengmay et al. OI. 237; 10 Jul. 2017; P (dried and spirit coll.), RUPP (dried coll. only).

LAO PDR • Champassak Province, Khong District; $14^{\circ} 5^{\prime} \mathrm{N}, 105^{\circ} 52^{\prime} \mathrm{E}$; alt. $97 \mathrm{~m}$; O. Insisiengmay et al. OI. 112; 17 Jun. 2016; P (spirit coll. only) - Mounlapamok District, Nong Nga village, Thong Nong Phue; $14^{\circ} 22^{\prime} \mathrm{N}, 105^{\circ} 30^{\prime} \mathrm{E}$; alt. 107 m; V. Lamxay et al. VL1881; 10 Jun. 2009; E, Natl. Univ. Laos, Fac. Science, SING, VNM. 
Table 3. Morphological comparison of Kaempferia larsenii Sirirugsa and Kaempferia pascuorum Insis. sp. nov.

\begin{tabular}{lll}
\hline Characters & Kaempferia larsenii & Kaempferia pascuorum sp. nov. \\
\hline 1. Leaves & & \\
Leafless sheath colour & Red & Green \\
Young shoot colour & Red & Green \\
Longest leaf blade & $90 \times 10 \mathrm{~mm}$ & $200 \times 25 \mathrm{~mm}$ \\
Petiole & Present & Absent \\
2. Inflorescence & & \\
Peduncle & Absent & $5-18 \mathrm{~mm}$ long \\
Flowers & 8 & $1-6$ \\
Floral tube & $55 \mathrm{~mm}$ long & $75-90 \mathrm{~mm}$ \\
Staminode colour & Pink & Pure white \\
Labellum colour & Pink with white patch at middle & White with purple patch at middle \\
Anther crest & Obovate, apex rounded, entire or & Flabellate, bifid, apex irregularly, \\
& slightly crenate, with pink patch & white \\
Filament & Absent & 2 mm long \\
\hline
\end{tabular}

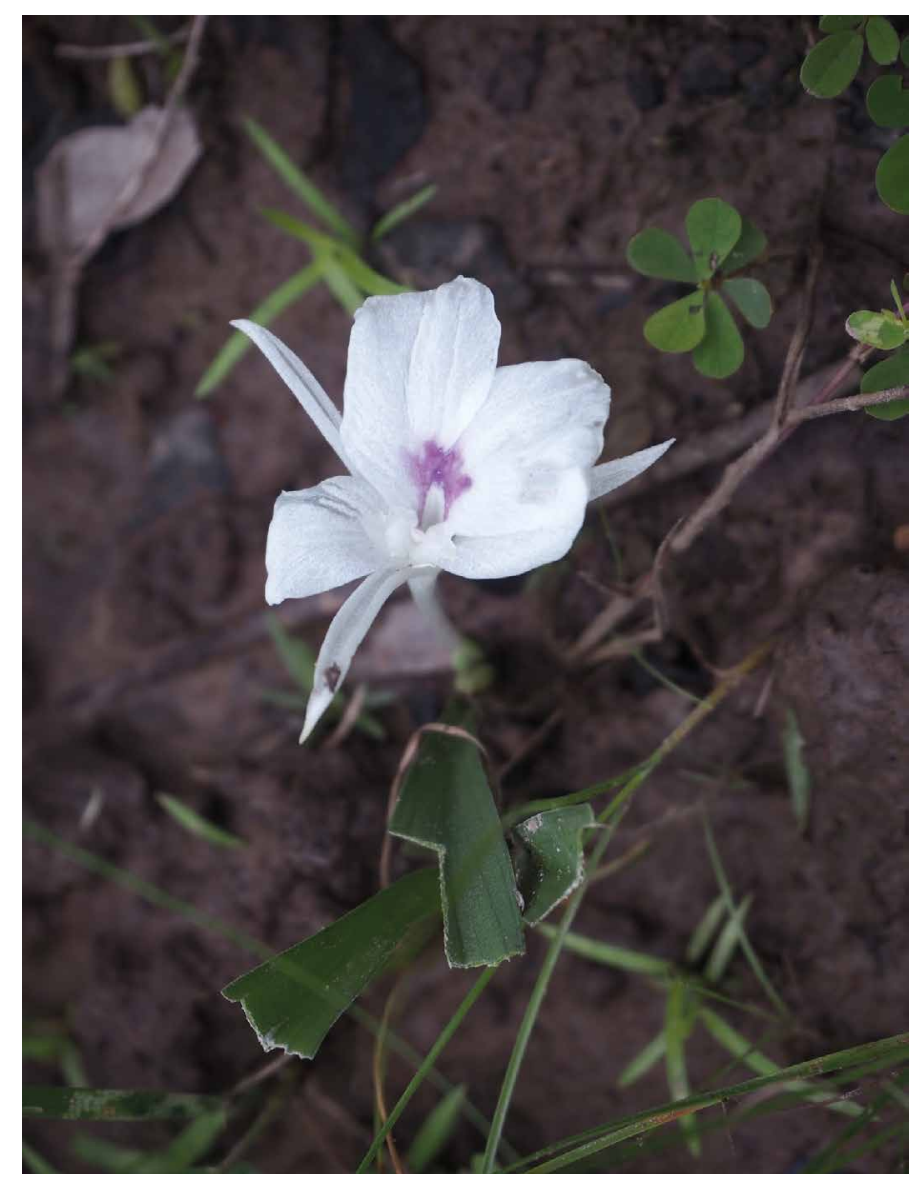

Fig. 4. Kaempferia pascuorum Insis. sp. nov. in natural habitat. Photograph: Oudomphone Insisiengmay. 


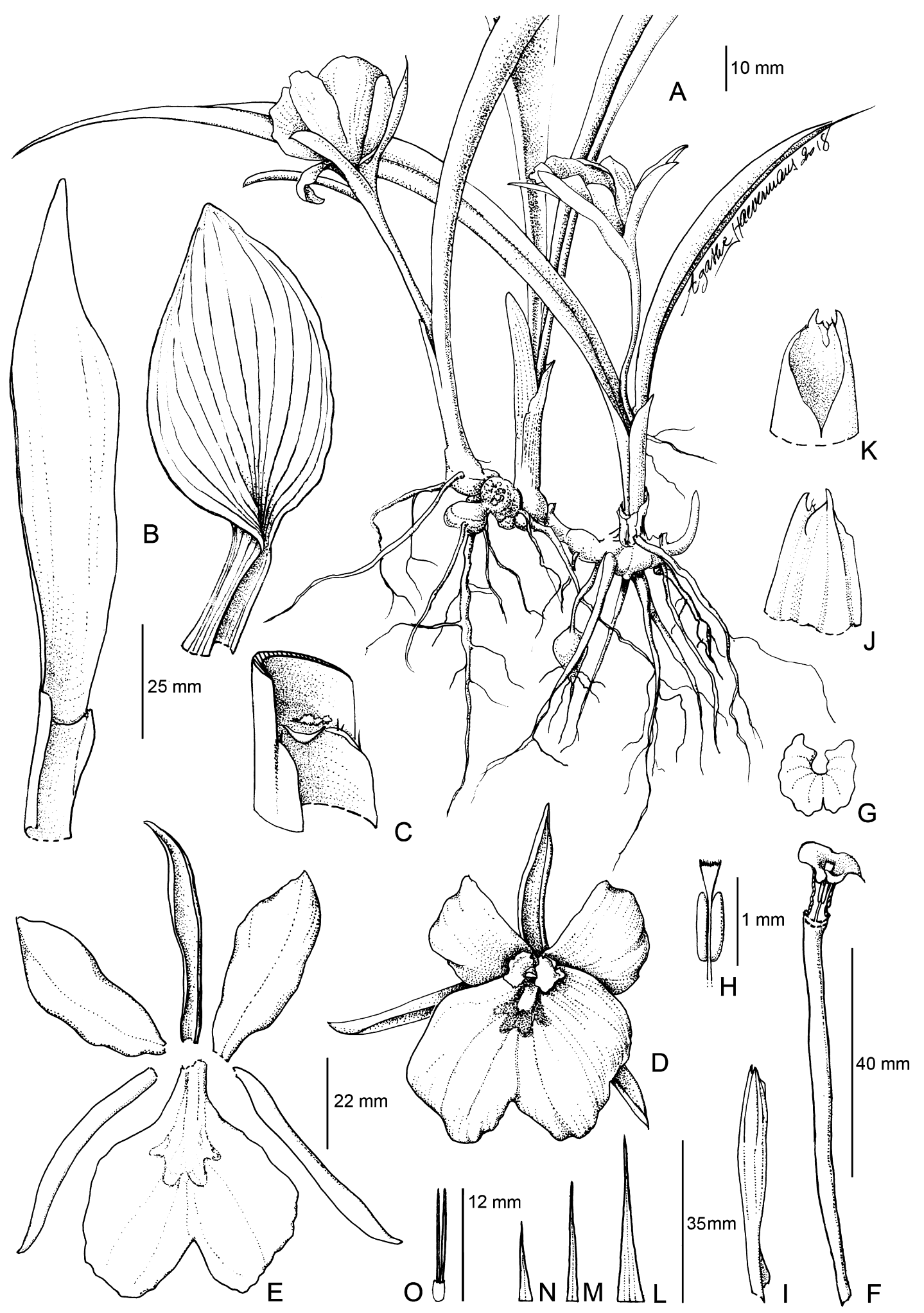

Fig. 5. Kaempferia pascuorum Insis. sp. nov. A. Whole plant. B. Leaves. C. Ligule. D. Flower. E. Flower dissected. F. Floral tube with anther attached. G. Anther crest from above. H. Stamen and stigma. I. Calyx. J-K. Apex of calyx from two different views. L. Bract. M-N. Bracteoles. O. Ovary and epigynous glands. Drawing from the type material by Agathe Haevermans (O. Insisiengmay et al. OI. $116)$. 


\section{Description}

Perennial herb, $6-10 \mathrm{~cm}$ tall. Rhizome short, horizontal; roots of two kinds, tuberous, ca $6-10 \times 3-5 \mathrm{~mm}$, and filamentous. Most individuals with one flowering shoot. Leaves two with two leafless sheaths, $10-50 \times$ 5-20 mm, green; ligule a very small rim at junction of sheath and blade, $<1 \mathrm{~mm}$ long, sparsely ciliate; longest leaf blade $200 \times 25 \mathrm{~mm}$, narrowly elliptic to narrowly ovate, erect, glabrous, base attenuate, apex attenuate; petiole absent. Inflorescence terminal, peduncle 5-18 mm long, flowers 1-6. Bracts narrowly elliptic, glabrous, $35 \times 4 \mathrm{~mm}$, hyaline, subtending a single flower; bracteoles 2 per flower, opposite, narrowly triangular to subulate, largest one $27 \times 1.5 \mathrm{~mm}$, diminishing to $25 \times 1 \mathrm{~mm}$, hyaline, glabrous. Calyx tubular, $45 \times 4 \mathrm{~mm}$ (not flattened), glabrous, apex 3-dentate, greenish and translucent; floral tube 75-90 $\times 4 \mathrm{~mm}$ (not flattened), glabrous, white; dorsal corolla lobe linear-acuminate, $40 \times 6 \mathrm{~mm}$, white, glabrous, apex with $5 \mathrm{~mm}$ long mucro; lateral corolla lobes linear-acuminate, $35 \times 5 \mathrm{~mm}$, white, glabrous, apex acute; lateral staminodes oblong, $30 \times 10 \mathrm{~mm}$, white, glabrous; labellum obcordate, 35-40 $\times 15-20 \mathrm{~mm}$, white with purple patch at centre, glabrous, apex bifid, divided to 15-20 mm, lobes emarginate; stamen attached at mouth of floral tube, filament $2 \mathrm{~mm}$ long, thecae $4 \mathrm{~mm}$ long, dehiscing by longitudinal slits, crest flabellate, $3 \times 5 \mathrm{~mm}$ to $12 \times 6 \mathrm{~mm}$, bifid, irregularly divided to $1-3 \mathrm{~mm}$, white, glabrous; epigynous glands two, subulate, $6-8 \mathrm{~mm}$ long; ovary cylindrical, $5 \times 3 \mathrm{~mm}$, glabrous, trilocular with axile placentation, ovules $2-6$ per locule, $1 \times 0.5 \mathrm{~mm}$; stigma $1 \mathrm{~mm}$ long, obcuneiform, curved longitudinally, ostiole ciliate. Fruit dehiscent irregularly, cylindrical, obovate-oblong, ca 10-15× 4-7 mm, calyx persistent; mature seeds not seen.

\section{Distribution and habitat}

Southern Lao PDR and Cambodia, paddy fields or in very open areas, in sandy soil.

\section{Conservation status}

Proposed IUCN status EN B1, B2, a, b(iii). EOO $=480 \mathrm{~km}^{2}, \mathrm{AOO}=12 \mathrm{~km}^{2}$. This species is only known at three locations near the Cambodian-Lao border, none of which is protected in law. The main threat in Lao PDR comes from agriculture, particularly the creation of pathways to and between fields. The Cambodian location is within a built-up area in Siem Pang town. It may be developed in future. The number of mature individuals found at each location is less than 20.

\section{Key to species of Kaempferia in Cambodia and Lao PDR}

1. Flowers appearing before leaves (subgenus Protanthium) ……................................................... 2

- Flowers and leaves appearing at the same time (subgenus Kaempferia) ........................................ 3

2. Leaves 2-4; blade oblong, green or purple, pubescent; petiole 10-20 mm long ........ K. rotunda $\mathrm{L}$.

- Leaves 5-7; blade elliptic, upper surface glabrous, lower pubescent; petiole absent

K. xiengkhouangensis Picheans. \& Phokham

3. Ligule present, $>2 \mathrm{~mm}$ long and clearly visible; flowers flat, directed upward 4

- Ligules very small, $\leq 2 \mathrm{~mm}$ long or absent; flowers cup-shaped, directed upward or sideward, or flat, directed upward

4. Leaves erect, blade oblong K. sawanensis Picheans. \& Koonterm

- Leaves flat on the ground, blade oblong or ovate to orbicular 5

5. Lateral staminodes and labellum pink to purple; anther crest pink, apex non bifid

K. marginata Carey ex Roscoe

- Lateral staminodes white; labellum white with violet patch; anther crest white, apex bifid 6 
6. Anther crest rectangular, bifid, divided by $1 \mathrm{~mm}$, apex rounded-emarginate ....... K. laotica Gagnep.

- Anther crest elliptic or cuneate-flabellate, bifid, divided to the base

7. Anther crest elliptic, $4 \times 4 \mathrm{~mm}$, lobes rounded

K. galanga L.

- Anther crest cuneate-flabellate, $6 \times 7 \mathrm{~mm}$, lobes emarginate-acute K. harmandiana Gagnep.

8. Nyctanthous (night-flowering) 9

- Hemeranthous (day-flowering)

9. Ligule present, $<1 \mathrm{~mm}$ long; blade ensiform, coriaceous; lateral staminodes spathulate; stamen sessile

K. fissa Gagnep.

- Ligule absent; blade subulate, soft; lateral staminodes obovate; stamen attached at mouth of floral tube, filament $2 \mathrm{~mm}$ long

K. filifolia K.Larsen

10. Bracteoles two per flower, fused at base, outside of floral tube puberulous

K. gigantiphylla Picheans. \& Koonterm

- Bracteoles two per flower, opposite, outside of floral tube glabrous .11

11. Ovary puberulous K. parviflora Wall. ex Baker

- Ovary glabrous 12

12. Leaf one, blade flat on the ground, orbicular K. siamensis Sirirugsa

- Leaf one to three, blade flat on the ground to erect, oblong to ovate 13

13. Floral tube $\leq 55 \mathrm{~mm}$ long; lateral staminodes obovate 14

- Floral tube $\geq 55 \mathrm{~mm}$ long; lateral staminodes oblong or obovate or spatulate 15

14. Rhizome short, vertical; lateral staminode and labellum pink, anther crest entire or slightly crenate with pink patch

K. larsenii Sirirugsa

- Rhizome short horizontal and very slender; lateral staminodes and labellum pure white; anther crest bifid and pure white K. champasakensis Picheans. \& Koonterm

15. Floral orientation sideward; floral tube $>90 \mathrm{~mm}$ long; staminodes oblong, $40 \times 12 \mathrm{~mm}$; anther crest obovate, $10 \times 6 \mathrm{~mm}$; ovary $8 \times 3.5 \mathrm{~mm}$ diameter

K. nemoralis Insis. sp. nov.

- Floral orientation upward; floral tube $\leq 90 \mathrm{~mm}$ long; staminodes oblong or spatulate; anther crest flabellate or narrowly ovate to ovate; ovary $5 \times 0.5-3 \mathrm{~mm}$ diameter

16. Floral tube $75-90 \mathrm{~mm}$ long; staminodes oblong, $30 \times 10 \mathrm{~mm}$; anther crest flabellate, $3 \times 5 \mathrm{~mm}$ to $12 \times 6 \mathrm{~mm}$, white; ovary $5 \times 3 \mathrm{~mm}$ diameter

K. pascuorum Insis. sp. nov.

- Floral tube 55-62 mm long; staminodes spatulate, $20 \times 12-16 \mathrm{~mm}$; anther crest narrowly ovate to ovate, $4-6 \times 3 \mathrm{~mm}$; ovary $5 \times 0.5 \mathrm{~mm}$ diameter.

K. attapeuensis Picheans. \& Koonterm

\section{Discussion}

This paper describes and illustrates two new species of Kaempferia, recently discovered in Cambodia and Lao PDR, adding to the overall biodiversity of these countries. A key is provided to distinguish the two new species from the other species known in these countries. The Vietnamese species of Kaempferia are not all included in this key because of the number of taxonomic uncertainties which remain. Further work is under way to produce a revision of Kaempferia in Cambodia, Lao PDR and Vietnam, including a molecular phylogenetic survey of the genus. More field collections are needed to complete our studies of poorly known species and to discover new taxa for which we have not yet obtained complete material. An assessment of the variation of species across their ranges is also required. In conclusion, our taxonomic 
and field work have already enriched botanical knowledge and collections, but more work is urgently needed in Cambodia, Lao PDR and Vietnam which are experiencing a high rate of deforestation and land conversion (Lang 2001).

\section{Acknowledgements}

The authors wish to thank the staff of the Ministry of Science and Technology, Lao PDR, especially Mrs Keophayvanh Douansavanh, general secretary of the Cabinet of the Lao Academy of Science and Technology and Mr Phouthasack Vichitra, director of the Cabinet. Also, the staff in Science and Technology at provincial and district level for all their support and help during our field work in Lao PDR. We are grateful to Assist. Prof. Dr Vichith Lamxay, Mr Sengmany Bouta and Miss Kobkeo Phethsomphou for their help. Mrs Youleang Peou, Mr Sovanrith Nheb and Miss Kunthea Chieb of the Department of Biology, Royal University of Phnom Penh, and Miss Sunisa Sangvirotjanapat, Chulalongkorn University, Bangkok assisted us greatly during our Cambodian field work. Mrs Agathe Haevermans made the beautiful drawings. The authors wish to thank the Franklinia Foundation who contributed to this fieldwork through a grant to the Muséum national d'histoire naturelle for the Flora of Cambodia, Laos and Vietnam. This paper is part of a project (AAP3-96) supported by the Sud Expert Plantes Developpement Durable programme. The Royal Botanic Garden Edinburgh (RBGE) is supported by the Scottish Government's Rural and Environmental Science and Analytical Services Division.

\section{References}

Applequist W.A. 2020. Report of the Nomenclature Committee for Vascular Plants: 71. Taxon 69: 391397. https://doi.org/10.1002/tax.12217

Baker J.G. 1890. Scitamineae. In: Hooker J.D. (ed.) Flora of British India 6: 218-224. Reeve \& Co, London. https://doi.org/10.5962/bhl.title.678

Beentje H. 2016. The Kew Plant Glossary, an illustrated Dictionary of Plant Terms. $2^{\text {nd }}$ edition. Kew Publishing Royal Botanic Garden.

Bentham G. \& Hooker J.D. (eds). 1883. Genera Plantarum 3: 642. Reeve \& Co, London. https://doi.org/10.5962/bhl.title.747

Burtt B.L. 1982. Cienkowskiella and Siphonochilus. Notes from the Royal Botanic Garden Edinburgh 40 (2): $369-373$.

Gagnepain F. 1908. Kaempferia. In: Lecomte H. (ed.) Flore générale de l'Indo-Chine 6: 45-56. Masson \& Co., Paris.

Holttum R.E. 1950. The Zingiberaceae of the Malay Peninsula. Gardens'Bulletin Singapore 13: 120.

Horaninow P. 1862. Prodromus Monographiae Scitaminearum Additis Nonnullis de Phytographia, de Monocotyleis et Orchideis. Petropoli. St. Petersburg. https://doi.org/10.5962/bhl.title.44562

Insisiengmay O. 2019. Systématique du genre Kaempferia L. (Famille des Zingiberaceae) au Cambodge, au Laos et au Vietnam (Systematics of Kaempferia L. (Zingiberaceae) in Cambodia, Laos and Vietnam). $\mathrm{PhD}$ thesis, Ecole doctorale sciences de la nature et de l'homme, Muséum national d'histoire naturelle, Paris.

Insisiengmay O., Newman M.F. \& Haevermans T. 2018. Proposal to conserve the name Kaempferia rotunda (Zingiberaceae) with a conserved type. Taxon 67 (1): 207-208. https://doi.org/10.12705/671.19

IPNI. 2020. International Plant Names Index. Available from http://www.ipni.org, The Royal Botanic Gardens, Kew, Harvard University Herbaria \& Libraries and Australian National Botanic Gardens [accessed 14 Apr. 2020]. 
IUCN. 2012. IUCN Red List Categories and Criteria. Version 3.1, second edition.

IUCN. 2017. Guidelines for Using the IUCN Red List Categories and Criteria. Ver. 13. Available from http://www.iucnredlist.org/documents/RedListGuidelines.pdf [accessed 6 Aug. 2020].

Kam Y.K. 1980. Taxonomic studies in the genus Kaempferia (Zingiberaceae). Notes from the Royal Botanic Garden Edinburgh 38 (1): 1-12.

Koonterm S. 2008. Kaempferia chayanii (Zingiberaceae), a new species from southern Laos. Folia Malaysiana 9 (1): 17-22.

Lang C. 2001. Deforestation in Vietnam, Laos and Cambodia. In: Vajpeyi D.K. (ed.) Deforestation, Environment, and Sustainable Development: A Comparative Analysis: 111-137. Praeger, Westport, Connecticut and London.

Mabberley D.J. 2017. Mabberley's Plant Book, $4^{\text {th }}$ edition. Cambridge University Press, Cambridge, UK.

Newman M.F., Ketphanh S., Svengsuksa S., Thomas P., Sengdala K., Lamxay V. \& Armstrong K. 2007. A Checklist of the Vascular Plants of Lao PDR. Royal Botanic Garden Edinburgh, Edinburgh.

Nopporncharoenkul N. \& Jenjittikul T. 2017. Kaempferia noctiflora (Zingiberaceae), a new species from Northern Thailand. Phytotaxa 316 (1): 67-72. https://doi.org/10.11646/phytotaxa.316.1.6

Nopporncharoenkul N. \& Jenjittikul T. 2018. Kaempferia graminifolia (subgen. Protanthium: (Zingiberaceae), a new species from Northern Thailand. Phytotaxa 379 (3): 261-266.

https://doi.org/10.11646/phytotaxa.379.3.4

Nopporncharoenkul N., Laongsri W. \& Jenjittikul T. 2020. Two new species of Kaempferia subgenus Protanthium (Zingiberaceae) from northern Thailand. Nordic Journal of Botany 38 (2): e02633.

https://doi.org/10.1111/njb.02633

Phokham B., Wongsuwan P. \& Picheansoonthon C. 2013. Three new species of Kaempferia (Zingiberaceae) from Thailand and Laos. Journal of Japanese Botany 88: 297-308.

Picheansoonthon C. 2009. Kaempferia sawanensis (Zingiberaceae), a new species from southern Laos. Acta Botanica Yunnanica 31 (6): 509-512.

Picheansoonthon C. 2010. Kaempferia lopburiensis (Zingiberaceae), a new species from Central Thailand. Journal of Japanese Botany 85 (3): 148-152.

Picheansoonthon C. 2011. Two new Kaempferia (Zingiberaceae) from Thailand. Journal of Japanese Botany 86: 1-8.

Picheansoonthon C. \& Koonterm S. 2008. A new species of Kaempferia (Zingiberaceae) from southern Laos. Taiwania 53 (4): 406-409.

Picheansoonthon C. \& Koonterm S. 2009a. A new species of Kaempferia L. (Zingiberaceae) from Northeastern Thailand. Taiwania 54 (1): 52-56.

Picheansoonthon C. \& Koonterm S. 2009b. Two new Kaempferia L. (Zingiberaceae) from southern Laos. Taiwania 54 (3): 219-225.

Schumann K.M. 1904. Zingiberaceae. In: Engler H.G.A. (ed.) Das Pflanzenreich IV, 46 (Heft 20): 38-88. Engelmann, Berlin.

Thiers B. continuously updated. Index Herbariorum: A global directory of public herbaria and associated staff. New York Botanical Garden's Virtual Herbarium.

Available from http://sweetgum.nybg.org/science/ih/ [accessed 6 Aug. 2020]. 
Turland N.J., Wiersema J.H., Barrie F.R., Greuter W., Hawksworth D.L., Herendeen P.S., Knapp S., Kusber W.-H., Li D.Z., Marhold K., May T.W., McNeill J., Monro A.M., Prado J., Price M.J., Smith G.F. (eds). 2018. International Code of Nomenclature for algae, fungi, and plants (Shenzhen Code) adopted by the Nineteenth International Botanical Congress, Shenzhen, China, July 2017. Regnum Vegetabile 159. Koeltz Scientific Books.

Wongsuwan P., Prasarn S. \& Picheansoonthon C. 2015. Kaempferia koontermii (Zingberaceae) - A new species from Thailand. Journal of Japanese Botany 90 (1): 29-33.

Wu D. \& Larsen K. 2000. Zingiberaceae. In: Wu Z. \& Raven P. (eds) Flora of China 24: 322-377. Science Press, Beijing \& Missouri Botanic Garden Press, St. Louis.

Manuscript received: 5 December 2018

Manuscript accepted: 10 June 2020

Published on: 4 September 2020

Topic editor: Frederik Leliaert

Desk editor: Connie Baak

Printed versions of all papers are also deposited in the libraries of the institutes that are members of the EJT consortium: Muséum national d'histoire naturelle, Paris, France; Meise Botanic Garden, Belgium; Royal Museum for Central Africa, Tervuren, Belgium; Royal Belgian Institute of Natural Sciences, Brussels, Belgium; Natural History Museum of Denmark, Copenhagen, Denmark; Naturalis Biodiversity Center, Leiden, the Netherlands; Museo Nacional de Ciencias Naturales-CSIC, Madrid, Spain; Real Jardín Botánico de Madrid CSIC, Spain; Zoological Research Museum Alexander Koenig, Bonn, Germany; National Museum, Prague, Czech Republic. 